\title{
Identifying Family-Work Conflict among employees of The Travancore Cements Limited, Kottayam, Kerala
}

\author{
Dhanya S Nair, M. Ayisha Millath
}

\begin{abstract}
Work- Family Interface is a bidirectional term which explains mainly two domains: Work- Family Conflict and WorkFamily Enrichment. Work-family Enrichment speaks about the bidirectional positive relationship of work and family. Work-family Conflict explains the negative bidirectional relationship of work and family. Many researchers are increasingly paying interest in Work-family interface as it can affect job satisfaction as well as life satisfaction. This paper investigates about the Family-work conflict among employees of The Travancore Cements Ltd., Kottayam, Kerala. The study was conducted among 81 employees of the organization. The finding of the study was that the employees are affected by Family-work conflict irrespective of their gender, education qualification, number of working hours per week, work experience, monthly income, marital status, number of school going children and partner's profession. In case of the number of children of employees, a significant difference is seen with regard to the variable 'family-related strain'.
\end{abstract}

Key Words: Demographic variables, Family-work conflict scale, Family-related Strain, Number of children.

\section{INTRODUCTION}

Work-family Interface (Sonja Drobnic, 2017) is relevant nowadays due to the emergence of nuclear families, dual earners in families and single parents. Work-family Interface consists of two phases: Work-family conflict and Work-family Enrichment (Sarika Jain, 2015), both of which are bidirectional. Work-family Conflict (Mina Beigi, 2018) is divided into work-family conflict scale and family-work conflict scale. While work-family conflict scale speaks about how factors in work bring conflict in family life, Family-work conflict scale tells about the factors in family life which brings conflict in work.

Since work and family are the two inseparable aspect of one's life, organizations must give utmost importance to make a balance between them. Many organizations provide family friendly policy to enhance the work-life balance of employees. Flexible working hours is one such technique provided by many organizations. Work-family conflict usually occurs when a person cannot properly make a balance between his work and family. It occurs when a person cannot spend adequate time in fulfilling each role, have strain in

Revised Manuscript Received on July 22, 2019.

Dhanya S Nair, Ph.D Research Scholar, Alagappa Institute of Management, Alagappa University, Karaikudi.

Dr. Ayisha Millath.M, Assistant Professor, Alagappa Institute of Management, Karaikudi. adjusting or fulfilling duties in each role, and behavior in one role is not compatible with other role.

Time- based conflict in work-family conflict scale occurs when there is work over load, long working hours, working at weekends and late nights. Family-work conflict occurs when too much time has to be spent with children, fulfilling household duties and more time to be spent with dependants.

Strain- based conflict in work-family conflict occurs when one cannot complete tasks on time, demands in work is affected by family responsibilities, life suffers as a result of fulfilling work responsibilities.

Behavior based conflict occurs when behavior expected for one role is not compatible with other role.

Work-family Conflict is not gender specific, it affects both female and males in this fast moving era. Since the number of women employees is rising considerably in each year, study of work-family interface becomes relevant. Not only gender, many other factors like income, work and family relationship, number of children affects work and family aspects.

\section{A. Family Work Conflict}

Even though work-family conflict (Surena Sabil, 2011)is based on both work-family conflict scale as well as family -work conflict scale, in this study the researchers considered only family-work conflict scale. Family-work conflict scale is a concept in which various factors in one's family life that contributes to conflict in work. An individual as an employee has two world in his life: work and family, so it is mandatory to study about his/her family circumstances (R.A Hamid, 2015). There are many factors in family life, which many of us ignore that are a hindrance to one's performance, productivity, mental health and well-being. In this study five variables considered were demand of family, family responsibilities, family related strain, relationship with partner and partner's profession. Demands of family mean the time and interactions you need to devote in your family life. If this demand increases, a person will find difficulty in dedicating time in his/her work thus leading to family-work conflict. Family responsibilities explain about child and dependent care, house hold responsibilities. Family related strain occur when an individual has old aged parents, non supportive partner and school going children, young children and personal as well as dependents

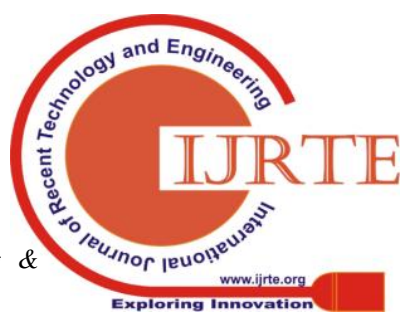


health problems. When the relationship with your partner is not open and cordial, an individual feels pressure and mental stress which affects work life. As in most of the households today, there are dual income earners; partner's profession becomes an unavoidable variable to be considered for the study (Sara Tement, 2010).

\section{B. The Travancore Cements Limited}

The Travancore Cements Limited, popularly known as "the house of white cements" was incorporated in the year 1946 and is situated near Vembanadu Lake, Kottayam, Kerala. It is a prestigious Public Sector Unit, which plays a pivotal role in Construction sector. The company was initially manufacturing grey cements from 1949 onwards and later moved on to manufacturing white cements, called as Vembanadu white cement from 1974.

\section{LITERATURE REVIEW}

When we think about reducing work-family conflict, most of the organizations consider flexible working hours as the best option. It has been stated in the study that the reasons for opting flexible work arrangements by the Faculties of Engineering Colleges in Trivandrum District of Kerala is mostly for "caring their children and old aged parents" followed by "to spend time with their family"(DS Nair, 2018). Staff - retention and recruitment, employee relations and motivation, employee commitment and loyalty are the major advantages of flexible working (Rankine, 2006).Flexible working hours influence job satisfaction and organizational commitment but it can affect performance directly or indirectly (Kelliher, Flexible Working and Performance: A Systematic Review of the Evidence for a Business Case, 2011).The use of flexible working hours has made the organization beyond boundaries and added new dimensions to business. With the advent of flexible working hours, the difficulty to manage work-life has been resolved.

It was discussed in(Sweet, 2004) that when studying about work and family interface, first thing that is to be considered is the biological circumstances such as age, gender, marital status etc. (Shelton, 2006) suggested that role management strategies can be discussed with women so that they can reduce the inter-role conflict to an extent. (Dr. R. Prabhakara Raya, 2013) family responsibilities done by women in their families have a significant impact on work-life balance. Another finding is that work pressure is an evident factor which causes work-family conflict (Helen Russell, 2009).

(Paul E. Spector, 2004) and (Luo Lu, 2008) pointed out that the long number of hours worked has a detrimental impact on the work-family balance. A significant finding is that work-family conflict has a direct impact on job performance (Dawn S. Carlson, 2009).Considering the gender, work-family conflict created adverse effect on women when compared to men (Rich, 2002).Further it was also investigated that women with "children 12 and under" are having increased work-family conflict as they find it difficult to meet family responsibilities and work responsibilities (Crouter, 1984).

(Beutell, 1985) concluded that the earlier concept of considering work and family as separate worlds no longer exists and emphasizes that both family and work are interdependent. (Mauno, 1998) examined that while job insecurity, poor leadership relations, full time employment as some of the work domain characteristic that caused work-family conflict, the family domain characteristics that caused family-work conflict were full time employment of spouse, number of children and number of school going children.

\section{STATEMENT OF THE PROBLEM}

The problems in an employee's family life may cause psychological problems which ultimately affects their organizational performance. There are several factors in a person's family life which leads to conflict in work. The Travancore Cements Limited is a Public Limited Company and a manufacturing unit of cements. The organization faces various conflicts among trade unions and management. Family- work conflict may be one of the causes of such disputes among employees and management. Strict and inflexible rules and regulations may make it difficult for the employees to manage work and family. Hence this study was framed to know about the Family- Work Conflict among employees at The Travancore Cements Limited, Kottayam.

\section{OBJECTIVES}

1. To understand the concept of "Family- Work Conflict" among employees at The Travancore Cements Limited, Kottayam.

2. To identify the factors associated with Family- Work Conflict.

3. To analyze the influence of demographic variables on Family- Work Conflict.

4. To identify whichclassification of demographic variable is significantly different with regard to family-work conflict scale.

\section{RESEARCH METHODOLOGY}

Using the reviews, structured questionnaire was developed and simple random sampling was adopted for the study. The Travancore Cements Limited, Kottayam consisted of a total of 150 employees among which 90 employees from various departments were distributed with a structured questionnaire. From the 90 questionnaires, 87 were returned and among which 81 reliable data were considered for the study. The demographic variables selected for the study were 'gender', 'educational qualification', 'number of working hours per week', 'work experience', 
'monthly income', 'marital status', 'number of children', 'number of school going children', 'partner's profession'. For measuring family-work conflict scale various factors considered were 'demands of family', 'family responsibilities', 'family-related strain' 'the relationship with partner' and 'partner's profession effect'.

\section{DATA ANALYSIS AND INTERPRETATION}

The objective of the study was to find out the influence of demographic variables on family- work conflict among the employees. For the same the questionnaire was designed in such a way that it included Likert scale questions for family-work conflict scale. The values taken for analysis are as follows: Highly agree-1, agree-2, neutral-3, disagree-4, highly disagree-5.One-Way ANOVA was used for analysis in the study.

Descriptive Analysis was done to understand the demographic profile of the respondents.Table-1 represent the frequency and its equivalent percent with regard to the sample respondents

Table 1: Descriptive Analysis of the Demographic Variables

\begin{tabular}{|c|c|c|c|c|}
\hline S. No & $\begin{array}{c}\text { Particula } \\
\text { r5 }\end{array}$ & $\begin{array}{l}\text { Classifica } \\
\text { tion of } \\
\text { variables }\end{array}$ & $\begin{array}{c}\text { Frequen } \\
\text { cy } \\
\mathrm{N}=81\end{array}$ & $\begin{array}{c}\text { Percenta } \\
\text { ge }\end{array}$ \\
\hline \multirow[t]{2}{*}{1} & \multirow[t]{2}{*}{ Gender } & Male & 62 & 76.5 \\
\hline & & Female & 19 & 23.5 \\
\hline \multirow[t]{4}{*}{2} & \multirow{4}{*}{$\begin{array}{l}\text { Educatio } \\
\text { nal } \\
\text { Qualifica } \\
\text { tion }\end{array}$} & SSLC & 26 & 32.1 \\
\hline & & $\begin{array}{l}\text { Plus two } \\
\text { ITIor } \\
\text { Diploma }\end{array}$ & $\begin{array}{l}11 \\
20\end{array}$ & $\begin{array}{l}13.6 \\
24.7\end{array}$ \\
\hline & & U.G & 16 & 19.8 \\
\hline & & $P . G$ & $B$ & 9.9 \\
\hline
\end{tabular}

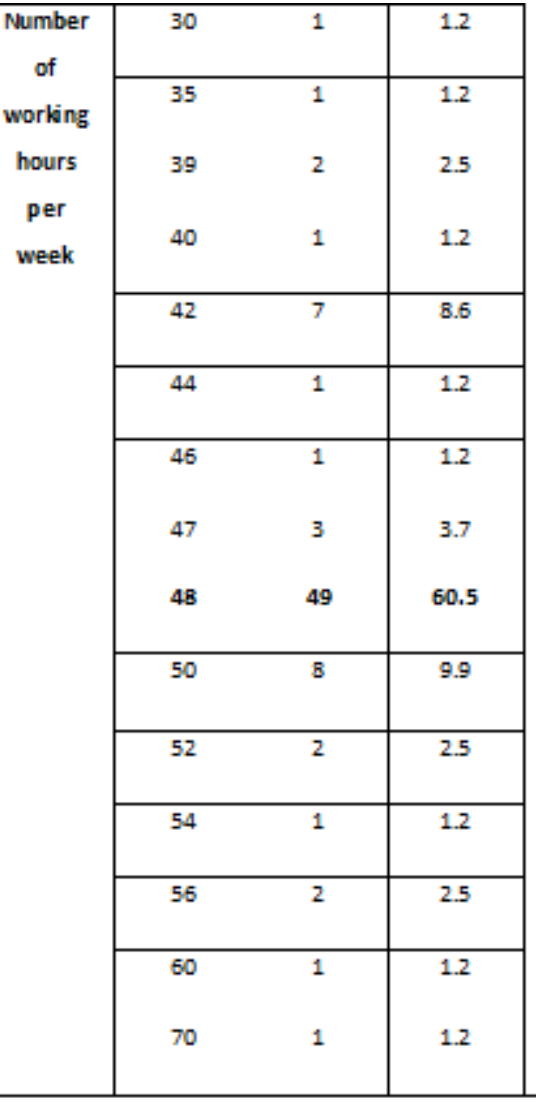

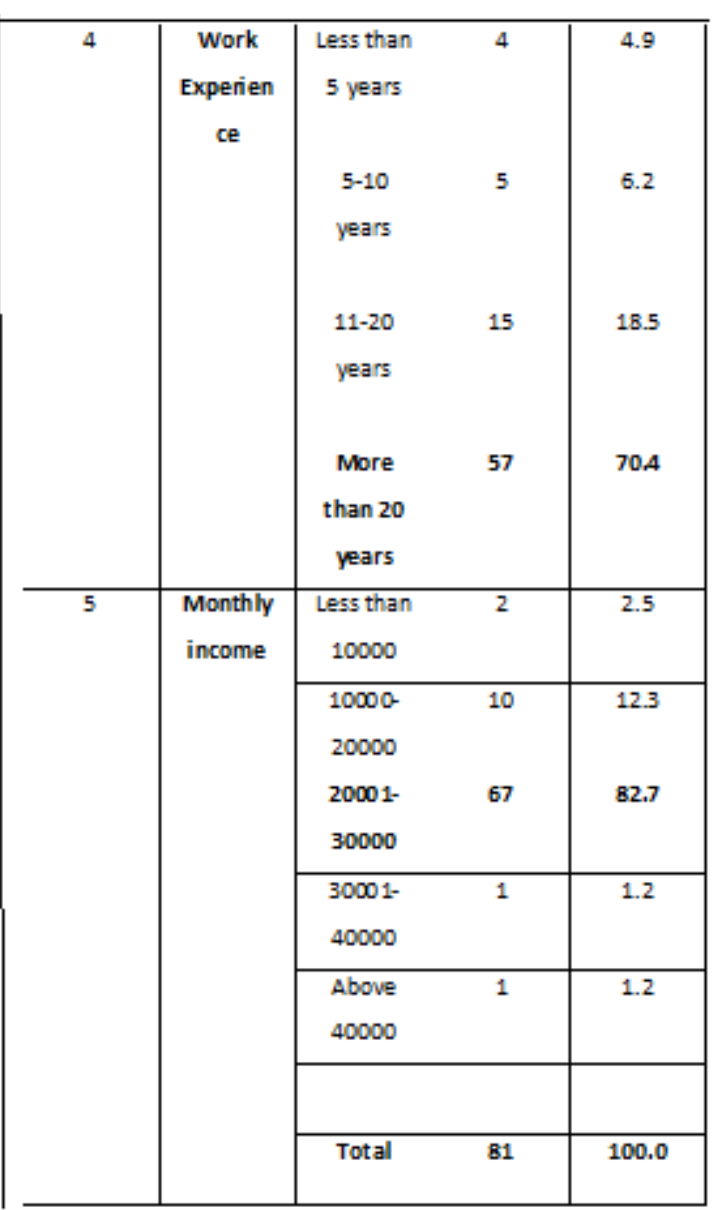


From the Table -1 , it is clear that most of the respondents were male $(76.5 \%)$.Educational qualification of majority of respondents were S.S.L.C (32.1\%).Most of them opined that 48 was the number of working hours per week $(60.5 \%)$. Work experience of most respondents was more than 20 years. Monthly income of majority of employees was 20001-30000 $(82.7 \%)$. Most of the respondents were married $(90.1 \%)$ and $(66.7 \%)$ of the respondents had 2-3 children. (55.6\%) opined that they have no school going children and $(23.5 \%)$ of them said that their partner's hadprofession other than business, IT, Health care, Academics, banking and insurance and marketing.

\section{H0: There is no significant difference between gender and family-work conflict scale.}

One way ANOVA was used to find the influence of gender and Family-Work Conflict. One way ANOVA compares the means among different groups and determines whether any of those means are statistically significantly different from each other

\begin{tabular}{|c|c|c|c|c|c|c|}
\hline \multicolumn{7}{|c|}{\begin{tabular}{|l} 
Table 2: Gender Vs Family-Work Conflict Scale \\
\end{tabular}} \\
\hline \multicolumn{2}{|c|}{$\begin{array}{l}\text { Family-Work Conflict } \\
\text { Variables }\end{array}$} & \multirow{2}{*}{$\begin{array}{r}\text { Sum of } \\
\text { Squares } \\
1.148\end{array}$} & \multirow{2}{*}{$\begin{array}{r}\text { df } \\
1\end{array}$} & \multirow{2}{*}{$\begin{array}{c}\text { Mean } \\
\text { Square } \\
1.148\end{array}$} & \multirow{2}{*}{$\begin{array}{l}\mathrm{F} \\
.662\end{array}$} & \multirow{2}{*}{$\begin{array}{r}\text { Sig. } \\
.418\end{array}$} \\
\hline \multirow{3}{*}{$\begin{array}{l}\text { Demands of } \\
\text { My Family }\end{array}$} & $\begin{array}{l}\text { Between } \\
\text { Groups } \\
\end{array}$ & & & & & \\
\hline & $\begin{array}{l}\text { Within } \\
\text { Groups }\end{array}$ & 137.025 & 79 & 1.734 & & \\
\hline & Total & 138.173 & 80 & & & \\
\hline \multirow{3}{*}{$\begin{array}{l}\text { Family } \\
\text { Responsibility }\end{array}$} & $\begin{array}{l}\text { Between } \\
\text { Groups }\end{array}$ & .351 & 1 & .351 & .279 & .599 \\
\hline & $\begin{array}{l}\text { Within } \\
\text { Groups }\end{array}$ & 99.205 & 79 & 1.256 & & \\
\hline & Total & 99.556 & 80 & & & \\
\hline \multirow{3}{*}{$\begin{array}{l}\text { Family-Relate } \\
\text { d Strain }\end{array}$} & $\begin{array}{l}\text { Between } \\
\text { Groups } \\
\end{array}$ & .736 & 1 & .736 & .500 & .482 \\
\hline & $\begin{array}{l}\text { Within } \\
\text { Groups }\end{array}$ & 116.400 & 79 & 1.473 & & \\
\hline & Total & 117.136 & 80 & & & \\
\hline \multirow{3}{*}{$\begin{array}{l}\text { Relationship } \\
\text { with Partner }\end{array}$} & $\begin{array}{l}\text { Between } \\
\text { Groups }\end{array}$ & .863 & 1 & .863 & .713 & .401 \\
\hline & $\begin{array}{l}\text { Within } \\
\text { Groups }\end{array}$ & 95.680 & 79 & 1.211 & & \\
\hline & Total & 96.543 & 80 & & & \\
\hline
\end{tabular}

\begin{tabular}{|l|l|r|r|r|r|r|}
\hline \multirow{2}{*}{$\begin{array}{l}\text { Partner's } \\
\text { Profession } \\
\text { Effect }\end{array}$} & $\begin{array}{l}\text { Between } \\
\text { Groups }\end{array}$ & 4.145 & 1 & 4.145 & 2.80 & .101 \\
\cline { 2 - 7 } & Within & 66.494 & 45 & 1.478 & & \\
\cline { 2 - 7 } & Groups & & & & & \\
\cline { 2 - 7 } & Total & 70.638 & 46 & & & \\
\hline
\end{tabular}

Since the $\mathrm{P}$ value is greater than 0.05 , the nullhypotheses in respect of all five variables 'demands of family', 'family responsibilities', 'family-related strain' and 'the relationship with partner' and 'partner's profession effect' are accepted. Hence, there is no significant difference between the workers of different gender with regard to the five variables considered forfamily-work conflict scale. All the workers irrespective of their gender have family-work conflict.

H0: There is no significant difference between educational qualification and family-work conflict scale.

One way ANOVA was used to find the influence of educational qualification and Family-Work Conflict

\begin{tabular}{|c|c|c|c|c|c|c|}
\hline \multicolumn{2}{|c|}{ Family-Work Conflict Variables } & \multirow{2}{*}{\begin{tabular}{r|}
$\begin{array}{c}\text { Sum of } \\
\text { Squares }\end{array}$ \\
2.220
\end{tabular}} & \multirow{2}{*}{\begin{tabular}{|l|} 
d \\
$\mathrm{f}$
\end{tabular}} & \multirow{2}{*}{\begin{tabular}{r}
\multicolumn{1}{c}{$\begin{array}{c}\text { Mean } \\
\text { Square }\end{array}$} \\
.555
\end{tabular}} & \multirow{2}{*}{\begin{tabular}{|c|}
$\mathrm{F}$ \\
.3 \\
10 \\
\end{tabular}} & \multirow{2}{*}{\begin{tabular}{|c}
$\mathrm{Si}$ \\
$\mathrm{g}$. \\
.8 \\
70 \\
\end{tabular}} \\
\hline \multirow{3}{*}{$\begin{array}{l}\text { Demands of My } \\
\text { Family }\end{array}$} & $\begin{array}{l}\text { Between } \\
\text { Groups }\end{array}$ & & & & & \\
\hline & $\begin{array}{l}\text { Within } \\
\text { Groups }\end{array}$ & 135.953 & $\begin{array}{l}7 \\
6 \\
\end{array}$ & 1.789 & & \\
\hline & Total & 138.173 & $\begin{array}{l}8 \\
0\end{array}$ & & & \\
\hline \multirow{3}{*}{$\begin{array}{l}\text { Family } \\
\text { Responsibility }\end{array}$} & $\begin{array}{l}\text { Between } \\
\text { Groups }\end{array}$ & .265 & 4 & .066 & $\begin{array}{c}.0 \\
51\end{array}$ & $\begin{array}{r}.9 \\
95\end{array}$ \\
\hline & $\begin{array}{l}\text { Within } \\
\text { Groups }\end{array}$ & 99.290 & $\begin{array}{l}7 \\
6 \\
\end{array}$ & 1.306 & & \\
\hline & Total & 99.556 & $\begin{array}{l}8 \\
0\end{array}$ & & & \\
\hline \multirow{3}{*}{$\begin{array}{l}\text { Family-Related } \\
\text { Strain }\end{array}$} & $\begin{array}{l}\text { Between } \\
\text { Groups }\end{array}$ & 4.393 & 4 & 1.098 & $\begin{array}{r}.7 \\
40 \\
\end{array}$ & $\begin{array}{r}.5 \\
67 \\
\end{array}$ \\
\hline & $\begin{array}{l}\text { Within } \\
\text { Groups }\end{array}$ & 112.743 & $\begin{array}{l}7 \\
6 \\
\end{array}$ & 1.483 & & \\
\hline & Total & 117.136 & $\begin{array}{l}8 \\
0\end{array}$ & & & \\
\hline $\begin{array}{l}\text { Relationship with } \\
\text { Partner }\end{array}$ & $\begin{array}{l}\text { Between } \\
\text { Groups }\end{array}$ & 4.096 & 4 & 1.024 & $\begin{array}{r}.8 \\
42 \\
\end{array}$ & $\begin{array}{r}.5 \\
03\end{array}$ \\
\hline
\end{tabular}




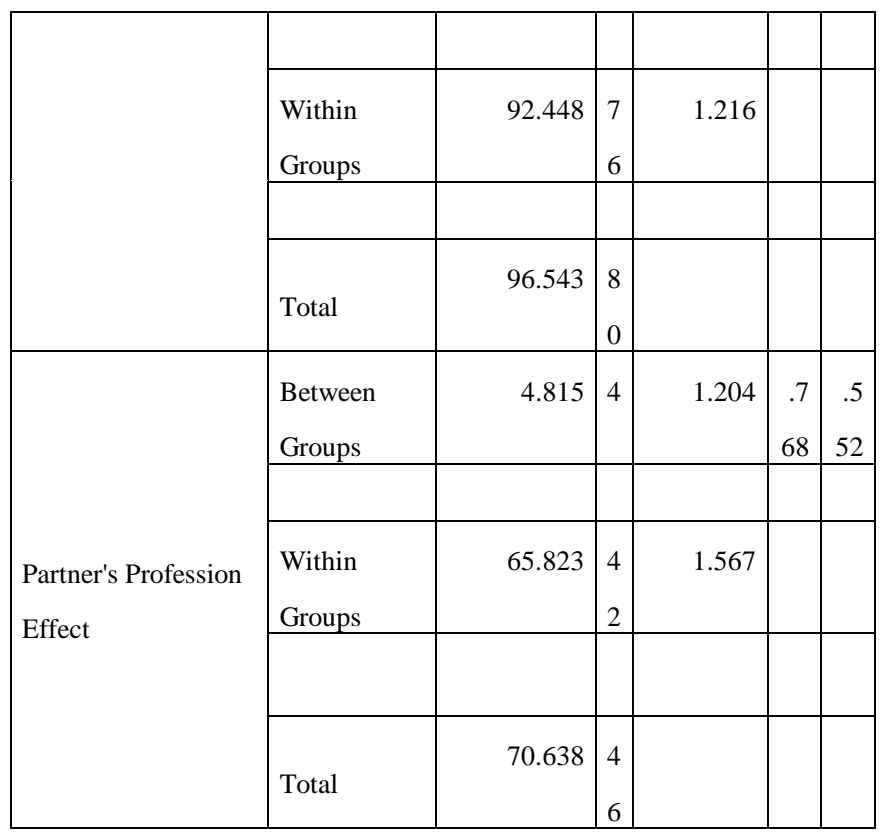

Since the $\mathrm{P}$ value is greater than 0.05 , the null hypotheses in respect of all five variables 'demands of family', 'family responsibilities', 'family-related strain' and 'the relationship with partner' and 'partner's profession effect' are accepted. Hence, there is no significant difference between the education qualifications of employees with regard to those five variables. All the workers irrespective of their educational qualification have family-work conflict.

\section{$H_{0:}$ There is no significant difference between number of working hours and family-work conflict scale.}

One way ANOVA was used to find the influence of number of worki on

Table 4:Number of Working hours per week Vs family-wol

Since the $\mathrm{P}$ value is greater than 0.05 , the null hypotheses in respect of all five variables 'demands of family', 'family responsibilities', 'family-related strain' and 'the relationship with partner' and 'partner's profession effect' are accepted. Hence, there is no significant difference between the numbers of working hours per week of employees with regard to those five variables. All the workers irrespective of their working hours have family-work conflict.

H0: There is no significant difference between work experience and family-work conflict scale.

One way ANOVA was used to find the influence of working experience and Family-Work Conflict.

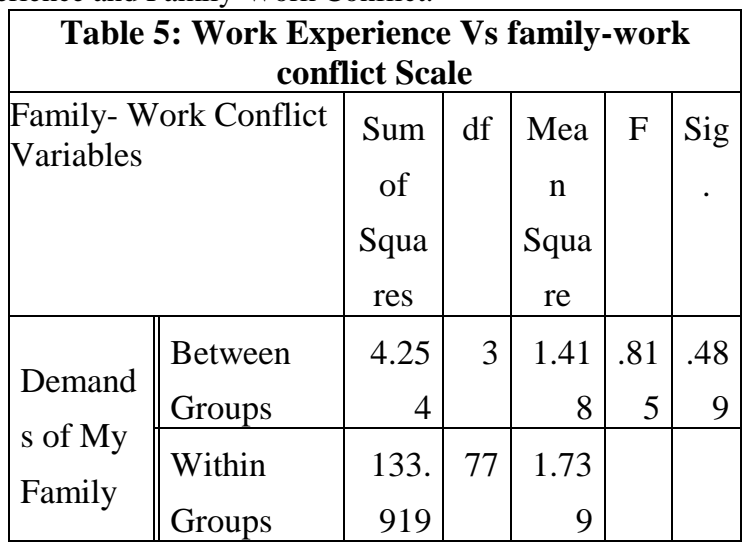

\begin{tabular}{|c|c|c|c|c|c|c|}
\hline & Total & $\begin{array}{r}138 . \\
173\end{array}$ & 80 & & & \\
\hline \multirow{5}{*}{$\begin{array}{l}\text { Family } \\
\text { Respons } \\
\text { ibility }\end{array}$} & Between & 1.46 & 3 & .487 & .38 & .76 \\
\hline & Groups & 1 & & & 2 & 6 \\
\hline & Within & 98.0 & 77 & 1.27 & & \\
\hline & Groups & 95 & & 4 & & \\
\hline & Total & $\begin{array}{r}99.5 \\
56\end{array}$ & 80 & & & \\
\hline \multirow{3}{*}{$\begin{array}{l}\text { Family- } \\
\text { Related } \\
\text { Strain }\end{array}$} & $\begin{array}{l}\text { Between } \\
\text { Groups }\end{array}$ & .603 & 3 & .201 & $\begin{array}{r}.13 \\
3 \\
\end{array}$ & $\begin{array}{r}.94 \\
0\end{array}$ \\
\hline & $\begin{array}{l}\text { Within } \\
\text { Groups }\end{array}$ & $\begin{array}{r}116 . \\
532\end{array}$ & 77 & $\begin{array}{r}1.51 \\
3\end{array}$ & & \\
\hline & Total & $\begin{array}{r}117 . \\
136 \\
\end{array}$ & 80 & & & \\
\hline \multirow{5}{*}{$\begin{array}{l}\text { Relation } \\
\text { ship } \\
\text { with } \\
\text { Partner }\end{array}$} & Between & 1.35 & 3 & .453 & .36 & .77 \\
\hline & Groups & 8 & & & 6 & 8 \\
\hline & Within & 95.1 & 77 & 1.23 & & \\
\hline & Groups & 85 & & 6 & & \\
\hline & Total & $\begin{array}{r}96.5 \\
43 \\
\end{array}$ & 80 & & & \\
\hline \multirow{5}{*}{$\begin{array}{l}\text { Partner's } \\
\text { Professi } \\
\text { on } \\
\text { Effect }\end{array}$} & Between & 5.55 & 3 & 1.85 & 1.2 & .31 \\
\hline & Groups & 9 & & 3 & 24 & 2 \\
\hline & Within & 65.0 & 43 & 1.51 & & \\
\hline & Groups & 79 & & 3 & & \\
\hline & Total & $\begin{array}{r}70.6 \\
38 \\
\end{array}$ & 46 & & & \\
\hline
\end{tabular}

Since the $\mathrm{P}$ value is greater than 0.05 , the null hypotheses in respect of all five variables 'demands of family', 'family responsibilities', 'family-related strain' and 'the relationship with partner' and 'partner's profession effect' are accepted. Hence, there is no significant difference between the work experiences of employees with regard to those five variables. All the workers irrespective of work experience have family-work conflict.

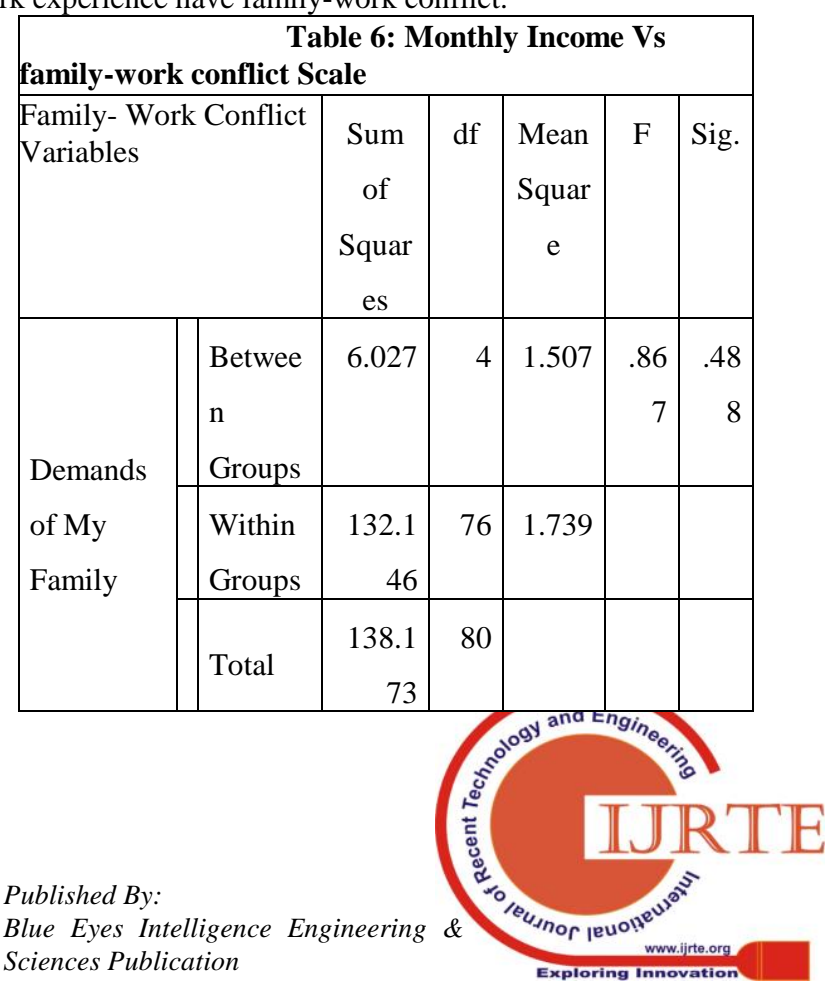


Identifying Family-Work Conflict among employees of The Travancore Cements Limited, Kottayam, Kerala

\begin{tabular}{|c|c|c|c|c|c|c|}
\hline \multirow{4}{*}{$\begin{array}{l}\text { Family } \\
\text { Responsib } \\
\text { ility }\end{array}$} & $\begin{array}{l}\text { Betwee } \\
n \\
\text { Groups }\end{array}$ & 3.284 & 4 & .821 & $\begin{array}{r}.64 \\
8\end{array}$ & $\begin{array}{r}.63 \\
0\end{array}$ \\
\hline & Within & 96.27 & 76 & 1.267 & & \\
\hline & Groups & 2 & & & & \\
\hline & Total & $\begin{array}{r}99.55 \\
6 \\
\end{array}$ & 80 & & & \\
\hline \multirow{4}{*}{$\begin{array}{l}\text { Family-Re } \\
\text { lated } \\
\text { Strain }\end{array}$} & $\begin{array}{l}\text { Betwee } \\
\mathrm{n} \\
\text { Groups } \\
\end{array}$ & 2.325 & 4 & .581 & $\begin{array}{r}.38 \\
5\end{array}$ & $\begin{array}{r}.81 \\
9\end{array}$ \\
\hline & Within & 114.8 & 76 & 1.511 & & \\
\hline & Groups & 10 & & & & \\
\hline & Total & $\begin{array}{r}117.1 \\
36 \\
\end{array}$ & 80 & & & \\
\hline \multirow{3}{*}{$\begin{array}{l}\text { Relationsh } \\
\text { ip with } \\
\text { Partner }\end{array}$} & $\begin{array}{l}\text { Betwee } \\
n \\
\text { Groups } \\
\end{array}$ & 8.598 & 4 & 2.150 & $\begin{array}{r}1.8 \\
58\end{array}$ & $\begin{array}{r}.12 \\
7\end{array}$ \\
\hline & $\begin{array}{l}\text { Within } \\
\text { Groups }\end{array}$ & $\begin{array}{r}87.94 \\
5 \\
\end{array}$ & 76 & 1.157 & & \\
\hline & Total & $\begin{array}{r}96.54 \\
3 \\
\end{array}$ & 80 & & & \\
\hline \multirow{3}{*}{$\begin{array}{l}\text { Partner's } \\
\text { Profession } \\
\text { Effect }\end{array}$} & $\begin{array}{l}\text { Betwee } \\
\mathrm{n} \\
\text { Groups } \\
\end{array}$ & 8.463 & 3 & 2.821 & $\begin{array}{r}1.9 \\
51\end{array}$ & $\begin{array}{r}.13 \\
6\end{array}$ \\
\hline & $\begin{array}{l}\text { Within } \\
\text { Groups }\end{array}$ & $\begin{array}{r}62.17 \\
5 \\
\end{array}$ & 43 & 1.446 & & \\
\hline & Total & $\begin{array}{r}70.63 \\
8\end{array}$ & 46 & & & \\
\hline
\end{tabular}

Since the $\mathrm{P}$ value is greater than 0.05 , the null hypotheses in respect of all five variables 'demands of family', 'family responsibilities', 'family-related strain' and 'the relationship with partner' and 'partner's profession effect' are accepted. Hence, there is no significant difference between the monthly incomes of employees with regard to those five variables. All the workers irrespective of monthly income have family-work conflict.

\section{$H_{0:}$ There is no significant difference between marital status and family-work conflict scale.}

One way ANOVA was used to find the influence of marital status and Family-Work Conflict.

\begin{tabular}{|l|c|c|c|c|c|}
\hline Conflict Scale & Table 7: Marital Status Vs family-work \\
\hline $\begin{array}{l}\text { Family- Work Conflict } \\
\text { Variables }\end{array}$ & $\begin{array}{c}\text { Sum of } \\
\text { Squares }\end{array}$ & df & $\begin{array}{c}\text { Mean } \\
\text { Square }\end{array}$ & F & Sig. \\
\hline
\end{tabular}

\begin{tabular}{|c|c|c|c|c|c|c|}
\hline \multirow{4}{*}{$\begin{array}{l}\text { Demands of } \\
\text { My Family }\end{array}$} & $\begin{array}{l}\text { Between } \\
\text { Groups }\end{array}$ & 5.591 & 3 & 1.864 & $\begin{array}{r}1.08 \\
2\end{array}$ & .362 \\
\hline & Within & 132.58 & 77 & 1.722 & & \\
\hline & Groups & 2 & & & & \\
\hline & Total & $\begin{array}{r}138.17 \\
3 \\
\end{array}$ & 80 & & & \\
\hline \multirow{3}{*}{$\begin{array}{l}\text { Family } \\
\text { Responsibil } \\
\text { ity }\end{array}$} & $\begin{array}{l}\text { Between } \\
\text { Groups }\end{array}$ & 2.595 & 3 & .865 & .687 & .563 \\
\hline & $\begin{array}{l}\text { Within } \\
\text { Groups }\end{array}$ & 96.960 & 77 & 1.259 & & \\
\hline & Total & 99.556 & 80 & & & \\
\hline \multirow{3}{*}{$\begin{array}{l}\text { Family-Rel } \\
\text { ated Strain }\end{array}$} & $\begin{array}{l}\text { Between } \\
\text { Groups }\end{array}$ & 5.854 & 3 & 1.951 & $\begin{array}{r}1.35 \\
0\end{array}$ & .264 \\
\hline & $\begin{array}{l}\text { Within } \\
\text { Groups }\end{array}$ & $\begin{array}{r}111.28 \\
2 \\
\end{array}$ & 77 & 1.445 & & \\
\hline & Total & $\begin{array}{r}117.13 \\
6 \\
\end{array}$ & 80 & & & \\
\hline \multirow{3}{*}{$\begin{array}{l}\text { Relationshi } \\
\text { p with } \\
\text { Partner }\end{array}$} & $\begin{array}{l}\text { Between } \\
\text { Groups }\end{array}$ & 8.050 & 3 & 2.683 & $\begin{array}{r}2.33 \\
5\end{array}$ & .080 \\
\hline & $\begin{array}{l}\text { Within } \\
\text { Groups }\end{array}$ & 88.493 & 77 & 1.149 & & \\
\hline & Total & 96.543 & 80 & & & \\
\hline
\end{tabular}

Since the $\mathrm{P}$ value is greater than 0.05 , the null hypotheses in respect of all four variables 'demands of family', 'family responsibilities', 'family-related strain' and 'the relationship with partner' are accepted. Partner's profession was not taken for test as at least one group had fewer than two cases. Hence, there is no significant difference between the marital statuses of employees with regard to those four variables. All the workers irrespective of marital status have family-work conflict.

H0: There is no significant difference between number of children and family-work conflict scale.

One way ANOVA was used to find the influence of number of children and Family-Work Conflict

Table 8:Number of children Vs family-work conflict Scale

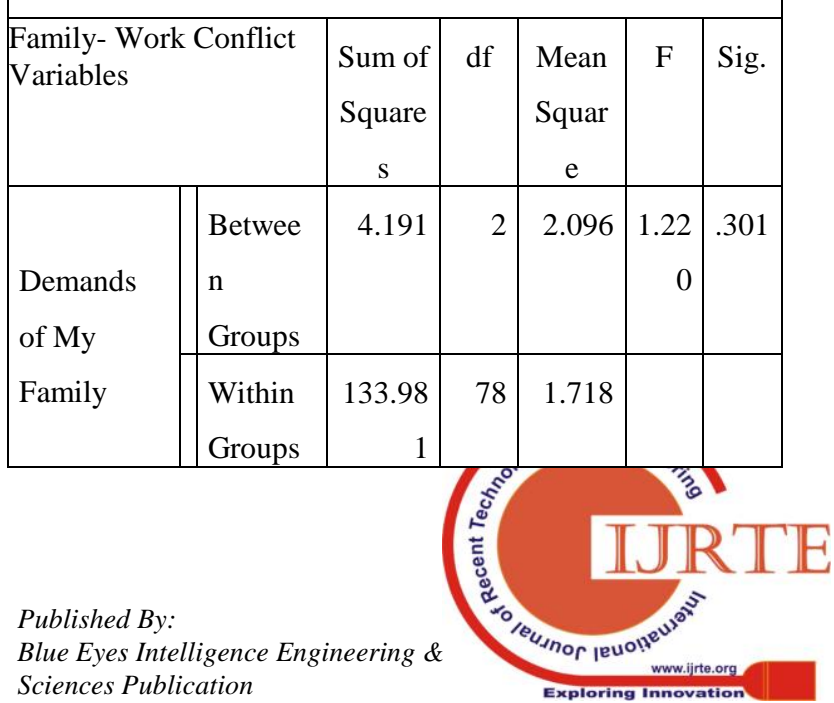




\begin{tabular}{|c|c|c|c|c|c|c|}
\hline & Total & $\begin{array}{r}138.17 \\
3 \\
\end{array}$ & 80 & & & \\
\hline \multirow{3}{*}{$\begin{array}{l}\text { Family } \\
\text { Responsibil } \\
\text { ity }\end{array}$} & $\begin{array}{l}\text { Betwee } \\
\text { n } \\
\text { Groups }\end{array}$ & 1.685 & 2 & .843 & .672 & .514 \\
\hline & $\begin{array}{l}\text { Within } \\
\text { Groups } \\
\end{array}$ & 97.870 & 78 & 1.255 & & \\
\hline & Total & 99.556 & 80 & & & \\
\hline \multirow{3}{*}{$\begin{array}{l}\text { Family-Rel } \\
\text { ated Strain }\end{array}$} & $\begin{array}{l}\text { Betwee } \\
\mathrm{n} \\
\text { Groups }\end{array}$ & 9.377 & 2 & 4.688 & $\begin{array}{r}3.39 \\
4\end{array}$ & .039 \\
\hline & $\begin{array}{l}\text { Within } \\
\text { Groups } \\
\end{array}$ & $\begin{array}{r}107.75 \\
9 \\
\end{array}$ & 78 & 1.382 & & \\
\hline & Total & $\begin{array}{r}117.13 \\
6 \\
\end{array}$ & 80 & & & \\
\hline \multirow{3}{*}{$\begin{array}{l}\text { Relationshi } \\
\text { p with } \\
\text { Partner }\end{array}$} & $\begin{array}{l}\text { Betwee } \\
\mathrm{n} \\
\text { Groups }\end{array}$ & 6.840 & 2 & 3.420 & $\begin{array}{r}2.97 \\
4\end{array}$ & .057 \\
\hline & $\begin{array}{l}\text { Within } \\
\text { Groups }\end{array}$ & 89.704 & 78 & 1.150 & & \\
\hline & Total & 96.543 & 80 & & & \\
\hline \multirow{3}{*}{$\begin{array}{l}\text { Partner's } \\
\text { Profession } \\
\text { Effect }\end{array}$} & $\begin{array}{l}\text { Betwee } \\
\text { n } \\
\text { Groups }\end{array}$ & 7.121 & 2 & 3.561 & $\begin{array}{r}2.46 \\
7\end{array}$ & .097 \\
\hline & $\begin{array}{l}\text { Within } \\
\text { Groups } \\
\end{array}$ & 63.517 & 44 & 1.444 & & \\
\hline & Total & 70.638 & 46 & & & \\
\hline
\end{tabular}

Since the $\mathrm{P}$ value is greater than 0.05 , the null hypotheses in respect of four variables 'demands of family', 'family responsibilities', 'the relationship with partner' and 'partner's profession effect' are accepted and there is no significant difference between the numbers of employees with regard to those four variables. Since the $P$ value is less than 0.05, the null hypothesis is rejected in respect of one variable i. e. family related strain. It shows that there exists significant difference between the numbers of children with regard to family related strain. Since the ANOVA test tells the overall difference between different groups only, a 'Post Hoc' test is carried out using 'Tukey HSD' method to know which groups are significantly different. The results of the tests are presented in the following tables. Post-hoc tests are not performed for Partner's Profession Effect because at least one group has fewer than two cases.

Table 9: Number of children Vs family-work conflict Scale: Post- Hoc Analysis

\begin{tabular}{|c|c|c|c|c|c|}
\hline Variables & $\begin{array}{c}\text { Number } \\
\text { of } \\
\text { children(I) }\end{array}$ & $\begin{array}{c}\text { Number } \\
\text { of } \\
\text { children } \\
(\mathrm{J})\end{array}$ & $\begin{array}{c}\text { Mean } \\
\text { differen } \\
\text { ce (I-J) }\end{array}$ & $\begin{array}{l}\text { S. } \\
\mathrm{E}\end{array}$ & $\begin{array}{c}\text { P } \\
\text { value }\end{array}$ \\
\hline $\begin{array}{c}\text { Family-Relate } \\
\text { d Strain }\end{array}$ & None & $\begin{array}{c}2-3 \\
\text { children }\end{array}$ & -1.037 & 42 & 0.04 \\
& & 3 & 0. & \\
\hline
\end{tabular}

There is a statistically significant difference between numbers of children of employees with respect of family-related strain as determined by ANOVA. The Post- Hoc test shows that the significant value $(\mathrm{P}=0.043)$ is less than 0.05 .The Post-hoc analysis reveals that there is significant difference among workers when the number of children is none and when it is 2-3 children with regard to family related strain.

\begin{tabular}{|c|c|c|c|c|}
\hline \multicolumn{5}{|c|}{ Table 10: Test of Homogeneity of Variances } \\
\hline \begin{tabular}{|l} 
Family- Work \\
Conflict Variables
\end{tabular} & $\begin{array}{l}\text { Levene } \\
\text { Statistic }\end{array}$ & $\mathrm{df} 1$ & df2 & Sig. \\
\hline $\begin{array}{l}\text { Demands of My } \\
\text { Family }\end{array}$ & .547 & 2 & 78 & .581 \\
\hline $\begin{array}{l}\text { Family } \\
\text { Responsibility }\end{array}$ & 1.366 & 2 & 78 & .261 \\
\hline $\begin{array}{l}\text { Family-Related } \\
\text { Strain }\end{array}$ & .778 & 2 & 78 & .463 \\
\hline $\begin{array}{l}\text { Relationship with } \\
\text { Partner }\end{array}$ & 1.653 & 2 & 78 & .198 \\
\hline $\begin{array}{l}\text { Partner's } \\
\text { Profession Effect }\end{array}$ & $3.482^{\mathrm{a}}$ & 1 & 44 & .069 \\
\hline
\end{tabular}

Since in the test of homogeneity, the significant values are above 0.05 , no further test is been done.

H0: There is no significant difference between number of school going children and family-work conflict scale.

One way ANOVA was used to find the influence of number of school going children and Family-Work Confl

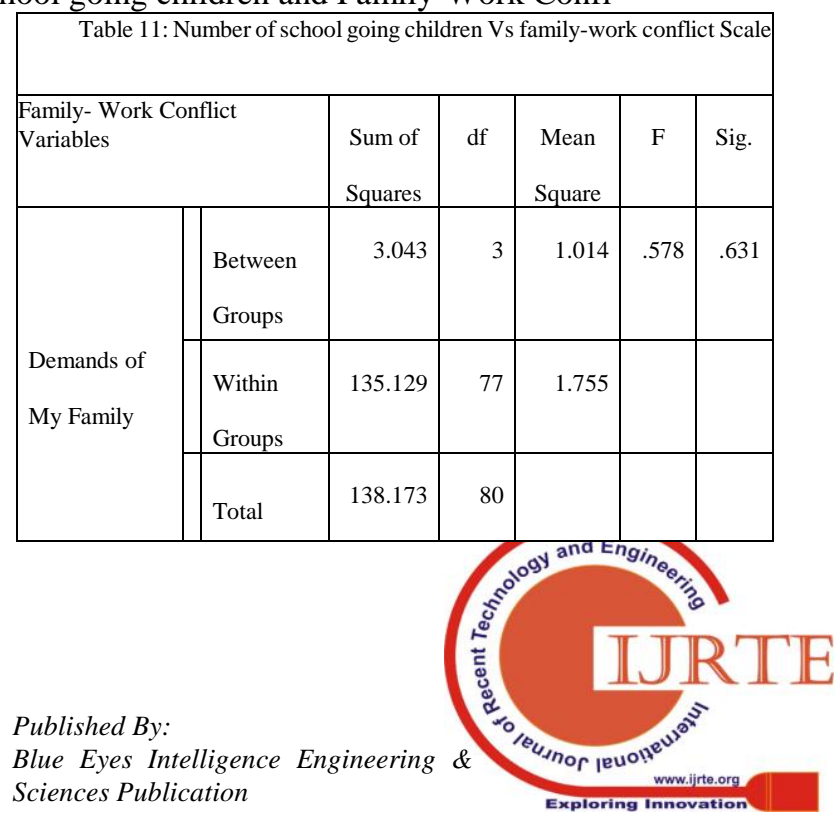




\begin{tabular}{|c|c|c|c|c|c|c|}
\hline \multirow{3}{*}{$\begin{array}{l}\text { Family } \\
\text { Responsibility }\end{array}$} & $\begin{array}{l}\text { Between } \\
\text { Groups }\end{array}$ & 2.426 & 3 & .809 & .641 & .591 \\
\hline & $\begin{array}{l}\text { Within } \\
\text { Groups }\end{array}$ & 97.129 & 77 & 1.261 & & \\
\hline & Total & 99.556 & 80 & & & \\
\hline \multirow{3}{*}{$\begin{array}{l}\text { Family-Relate } \\
\text { d Strain }\end{array}$} & $\begin{array}{l}\text { Between } \\
\text { Groups }\end{array}$ & 1.399 & 3 & .466 & .310 & .818 \\
\hline & $\begin{array}{l}\text { Within } \\
\text { Groups }\end{array}$ & 115.737 & 77 & 1.503 & & \\
\hline & Total & 117.136 & 80 & & & \\
\hline \multirow{3}{*}{$\begin{array}{l}\text { Relationship } \\
\text { with Partner }\end{array}$} & $\begin{array}{l}\text { Between } \\
\text { Groups }\end{array}$ & .529 & 3 & 176 & .141 & .935 \\
\hline & \begin{tabular}{|l} 
Within \\
Groups \\
\end{tabular} & 96.014 & 77 & 1.247 & & \\
\hline & Total & 96.543 & 80 & & & \\
\hline \multirow{3}{*}{$\begin{array}{l}\text { Partner's } \\
\text { Profession } \\
\text { Effect }\end{array}$} & $\begin{array}{l}\text { Between } \\
\text { Groups }\end{array}$ & 7.477 & 3 & 2.492 & $\begin{array}{r}1.69 \\
7\end{array}$ & .182 \\
\hline & $\begin{array}{l}\text { Within } \\
\text { Groups }\end{array}$ & 63.161 & 43 & 1.469 & & \\
\hline & Total & 70.638 & 46 & & & \\
\hline
\end{tabular}

Since the $\mathrm{P}$ value is greater than 0.05 , the null hypotheses in respect of all five variables are 'demands of family', 'family responsibilities', 'family-related strain' and 'the relationship with partner' and 'partner's profession effect' are accepted. Hence, there is no significant difference between the numbers of school going children of employees with regard to those five variables. All the workers irrespective of number of school going children have family-work conflict.

\section{H0: There is no significant difference between partner's profession and family-work conflict scale.}

One way ANOVA was used to find the influence of partner's profession and Family-Work Conflict.

\section{FINDINGS AND DISCUSSION}

Five variables 'demands of family', 'family responsibilities', 'family-related strain' and 'the relationship with partner' and 'partner's profession effect' were selected for studying family-work conflict scale and One-way ANOVA was conducted to analyze whether there is any significant difference between demographic variables and family-work conflict scale. The study concluded that with regard to 'gender', 'education qualification', 'number of working hours per week', 'work experience', 'monthly income', 'marital status', 'number of school going children', 'Partner's profession', there is no significant difference with regard to family-work conflict. While in case of number of children, there is a significant difference in case of one of the variable $i$ .e, family related strain. Thus a Post-hoc test was conducted to understand which category was significantly different. Through the Post-hoc test, it was revealed that the difference was seen when number of children was none and also when it was $2-3$ children with respect to family related strain.

\section{CONCLUSION}

Work-family conflict is a bidirectional concept which consists of work-family conflict scale as well as family-work conflict scale. This study was confined to only family- work conflict scale. The organization must pay attention to the five variables 'demands of family', 'family responsibilities', 'family-related strain' and 'the relationship with partner' and 'partner's profession effect' considered in this study with regard to family-work conflict scale. It is inevitable because these factors can reduce the performance and productivity of employees in both work and family. Organization can introduce family friendly policies like flexible working hours, stress coping methods such as counselling programs marital enrichment programs so that individuals can satisfy both their roles. It was interpreted from this study also individuals irrespective of their 'gender', 'education qualification', 'number of working hours per week', 'work experience', 'monthly income', 'marital status', 'number of school going children', 'Partner's profession'. So it is advisable to provide family-friendly arrangements to all employees equally. Organization can think of making flexible working arrangements more when the number of children and dependents of an employee is more in order to reduce family related strain.

On the other hand, in families there must be an open and caring atmosphere so that employed men and women can share their stress and work pressure. Partner and dependents must cooperate and support individuals in sharing family responsibilities to reduce the inter-role conflict. Family members can support individuals to engage in hobbies, outing and physical exercises like yoga and out-door games so that it helps them to have a good bond between family members

\section{REFERENCES}

1. Beutell, J. H. (1985). Sources of Conflict Between Work and Family Roles. Academy of management review , 76-88.

2. Crouter, A. C. (1984). Spillover from Family to Work: The Neglected Side of the Work-Family Interface. Human Relations , 425-442.

3. Dawn S. Carlson, J. G. (2009). The relationship of schedule flexibility and outcomes via the work-family interface. Journal of managerial psychology , 330-355.

4. Dr. R. Prabhakara Raya, G. D. (2013). A study on Work-Life Balance in Working Women. International Journal of Commerce, Business and Management .

5. DS Nair, Dr. M. Ayisha Millath (2018). An Analytical study on the influence of Gender on the reasons for opting flexible working Hours among Faculties of Engineering colleges in Trivandrum District of Kerala. Zenith International Journal of multidisciplinary research , 195-200.

6. Helen Russell, P. J. (2009). The Impact of Flexible Working Arrangements on Work-Life Conflict and Work Pressure in Ireland. Gender, Work \& Organisation , 73-97. 
7. Kelliher, L. M. (2011). FlexibleWorking and Performance: A Systematic Review of the Evidence for a Business Case. International Journal of Management Reviews , 452-474.

8. Luo Lu, S.-F. K.-T.-P. (2008). Work/Family Demands, Work Flexibility, Work/Family Conflict, and Their Consequences at Work:A National Probability Sample in Taiwan. International Journal of stress management , 1-21.

9. Mauno, U. K. (1998). Antecedents and outcomes of Work family Conflict among married women and men in Finland. Human Relations .

10.Mina Beigi, M. S. (2018). Flexible work arrangements and work-family conflict: A metasynthesis of qualitative studies among academics. Human resource Development review .

11. Paul E. Spector, C. L. (2004). A Cross-national Comparative Study Of Work-Family Stressors, Working hours, And Well-being: China And Latin America VERSUS The Anglo World. Personnel Psychology, 119-142

12. R.A Hamid, U. U. (2015). The effect of work-family conflict and work-family enrichment on the affective organizational committment among faculty clerical staff in UTM Skudai. Journal of Advanced Research in social and behavioural Sciences , 43-59.

13.Rankine, G. M. (2006). The incidence and impact of flexible working arrangements in smaller businesses. Employee Relations , 138-161.

14.Rich, R. G. (2002). Profiles of Attribution of Importance to Life Roles and Their Implications for the Work-Family Conflict . Journal of counselling psychology , 212-220.

15. Sara Tement, C. K. (2010). Towards the Assessment of the work -family Interface : Validation ofthe slovenian versions of work-family conflict and work-family enrichment scales. Horizons of psychology , 53-74.

16. Sarika Jain, D. S. (2015). Role of demographic variables in Work-Family Enrichment: A study of sales employees in India. International Journal of Business and Management .

17.Shelton, L. M. (2006). Female Entrepreneurs, Work-Family Conflict, and Venture Performance: New Insights into the Work-Family Interface. Journal of Small Business Management, 285-297.

18.Sonja Drobnic, P. P. (2017). Work-family Enrichment and Gender Inequalities in Eight European Countries. International Journal of Human Resource Management .

19.Surena Sabil, S. M. (2011). Working hours, Work-family Conflict and Work -family Enrichment among Professional Women. International Conference on Social science and humanity. Singapore.

20. Sweet, P. M. (2004). From 'work-family' to 'flexible careers'. Community, Work \& Family , 209-226. 